\title{
The Citrate Metabolism in Homo- and Heterofermentative LAB: A Selective Means of Becoming Dominant over Other Microorganisms in Complex Ecosystems*
}

\author{
Gemelas Laëtitia1, Degraeve Pascal'2, Demarigny Yann' ${ }^{1 \#}$ \\ ${ }^{1}$ Isara-Lyon, Agrapôle, Food Microbiology Laboratory, BIODYMIA, Lyon, France \\ ${ }^{2}$ Lyon 1 University, Research Laboratory in Industrial Engineering Food-BIODYMIA EA 373, \\ Bourg-en-Bresse, France \\ Email: Igemelas@isara.fr, pascal.degraeve@univ-lyon1.fr, ,
}

Received 20 March 2014; revised 20 April 2014; accepted 27 April 2014

Copyright $@ 2014$ by authors and Scientific Research Publishing Inc.

This work is licensed under the Creative Commons Attribution International License (CC BY). http://creativecommons.org/licenses/by/4.0/

(c) (i) Open Access

\begin{abstract}
The citrate metabolism has been extensively studied in lactic acid bacteria (LAB) for its aroma compound production. Among the 4-carbon $\left(\mathrm{C}_{4}\right)$ by-products obtained from citrate fermentation, diacetyl is one of the better known products for its contribution to the buttery aroma of dairy products. A lot of documents deal with ways to improve diacetyl concentration in food matrices. Apart from these organoleptic advantages, in a microbial ecosystem, the citrate metabolism gives selective advantages to citrate positive microorganisms. Citrate metabolism allows the LAB to use another carbon source for their growth, withstand acidic conditions and generate a "proton motive force" (PMF). Moreover, the citrate/glucid co-metabolism leads to the fast release of organic compounds known for having bacteriostatic effects. Under specific conditions, the $\mathrm{C}_{4}$ pathway liberates diacetyl which is bacteriostatic. In this review we first describe the citrate metabolism and the enzymes involved in the two homo- and heterofermentative LAB Lc diacetylactis and Leuconostoc spp. Moreover, the way to shift the metabolic pathway toward the production of aromatic compounds is discussed for both of these fermentative types of bacteria. Finally, the selective advantages of citrate metabolism for $\mathrm{LAB}$ in complex microbial ecosystems are delineated.
\end{abstract}

\section{Keywords}

Citrate Metabolism, Lactococcus lactis subsp. lactis biovar. diacetylactis, Leuconostoc spp., Complex Microbial Ecosystems, Homo- and Heterofermentative Lactic Acid Bacteria

\footnotetext{
*The homo- and heterofermentative lactic acid bacteria (LAB) are illustrated by Leuconostoc and Lactococcus species.

\#Corresponding author.

How to cite this paper: Laëtitia, G., et al. (2014) The Citrate Metabolism in Homo- and Heterofermentative LAB: A Selective Means of Becoming Dominant over Other Microorganisms in Complex Ecosystems. Food and Nutrition Sciences, 5, 953-969. http://dx.doi.org/10.4236/fns.2014.510106
} 


\section{Introduction}

The citrate molecule is abundant in nature. It is an important source of energy for many bacteria in food matrices such as fruits, vegetables or cheeses. For instance, the citrate concentration in raw cow milks ranges from 1.25 to $2.00 \mathrm{~g} / \mathrm{L}$. In the food industry, citrate salts are added as buffer substances or sometimes as fungistatic agents. This molecule is also a key compound for different metabolic routes, such as the Krebs Cycle. Most bacteria possess transport systems in the cytoplasmic membrane that mediate the uptake of citrate, e.g. Klebsiella pneumoniae, Salmonella typhymurium, Escherichia coli, Bacillus subtilis and some lactic acid bacteria (LAB) [1]. Internalized citrate can be utilized as a carbon and energy source under aerobic as well as under anaerobic conditions. If the aerobic metabolism implies a functional tricarboxylic acid cycle, under anaerobic conditions the fermentative pathways are different. For instance, three pathways have been described in Enterobacteriaceae [2]. The citrate positive LAB ferment the citrate under strict anaerobic condition [3]. After the depletion of lactose at the end of the cheesemaking process, citrate is a possible carbon source used by the mesophilic lactobacilli to support their growth during cheese ripening [4]. Under acidic conditions and in the presence of citrate, citrate metabolism liberates 4-carbon $\left(\mathrm{C}_{4}\right)$ compounds: diacetyl, acetoin, and 2,3-butanediol. Among them, diacetyl and acetoin are known to exhibit nutty and buttery aromatic notes. Lactococcus lactis subsp. lactis biovar. diacetylactis, few Leuconostoc, few Enterococcus, Lactobacillus plantarum and Oenococcus oeni are known as diacetyl and acetoin producers [5]-[9]. The improvement of diacetyl yields in food technology has been extensively studied in the two QPS—Qualified Presumption of Safety-LAB, Lactococcus lactis subsp. lactis biovar. diacetylactis (hereafter designated as LD) and some citrate positive Leuconostoc spp. (cpLN hereafter). Citrate metabolism is regulated by different environmental factors whatever the type of metabolic route involved, homo or heterofermentative. Besides, the metabolic engineering involved in rerouting the carbon metabolism has been discussed in numerous studies (for reviews, see [7] [10] [11], for original articles, see [12]-[15]). Citrate metabolism can also be seen as a selective advantage for LAB in a complex microbial ecosystem. Indeed, citrate positive LAB show a higher resistance to lactate toxicity [16]. The citrate/glucid co-metabolism, which increases the maximum specific growth rate and the growth yield under acidic conditions, leads to a rapid ground invasion and the associated barrier effect [17] [18]. This additional catabolism generates a "proton motive force" (PMF). As well as energy-rich phosphate-bond intermediates such as ATP (adenosine triphosphate), the PMF is a metabolic energy source required for all the energy-requiring processes in the living cells. As sugar fermentation provides low ATP yields, the electrochemical energy generated via a proton gradient appears essential to support the metabolic activity of fermentative microorganisms. Besides, in their natural environment, LAB are more likely to be subjected to sugar starvation. The PMF generated by citrate metabolism enables the LAB to withstand energy depletion for short periods of time. The viability of the culture depends on the physiological state of the cell before the onset of the starvation period. When nutritional conditions are restored, glucidic fermentation restarts with the concomitant production of ATP and the recovery of LAB growth [19]. The citrate/glucid co-metabolism leads to the fast release of acetic acid in great amounts. Weak acids are known to have bacteriostatic effects at $\mathrm{pH}$ values below their pKa. Under specific conditions, this pathway liberates significant amounts of diacetyl also known as an antimicrobial agent.

In this review, we first describe the diverse pathways and key-regulators involved in the production of aromatic compounds for homo (such as LD) and heterofermentative (such as LN) bacteria. In particular, we emphasize the different factors that can inhibit or activate each metabolic step. Then we delineate the selective advantages of this metabolism in complex microbial ecosystems.

\section{Part 1: Citrate Metabolic Pathway}

\subsection{Initial Breakdown of Citrate to Obtain Pyruvate}

The first steps of the citrate metabolism include the internalization of the molecule followed by its breakdown to obtain pyruvate. This is observed in both homo- (Figure 1) and heterofermentative (Figure 2) LAB. This catabolism is unstable for LD and cpLN because one or the two gene clusters involved in the internalization and the first steps of the citrate breakdown are plasmid-encoded. Three steps lead to pyruvate synthesis. Firstly, citrate is taken up by the citrate permease (CitP), a member of the 2-hydroxycarboxylate family transporters. Then citrate breakdown inside the cell involves its conversion into acetate and oxaloacetate (OxA) by the action of the citrate lyase (CL). Finally, OxA is decarboxylated by the oxaloacetate decarboxylase (OAD) into pyruvate and carbon dioxide. 


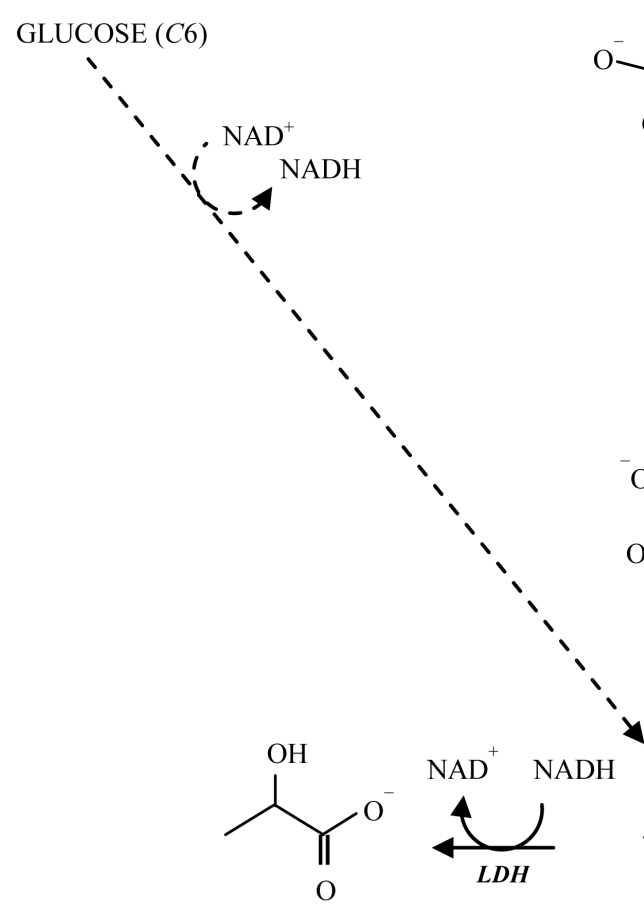<smiles>O=C([O-])C=COC(=O)C(O)(CC(=O)[O-])CC(=O)[O-]</smiles>

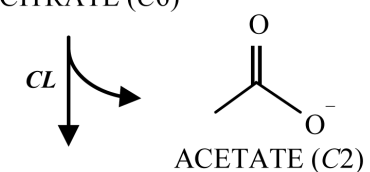<smiles>O=C([O-])CC(=O)C(=O)[O-]</smiles>

OXALOACETATE (C4)

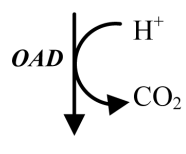

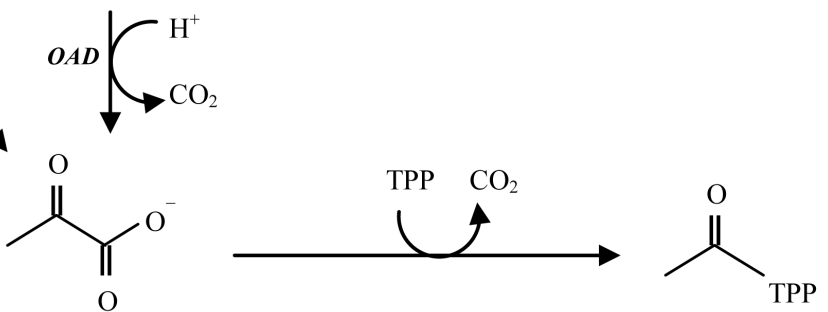

LACTATE (C3)

$\mathrm{O}$

VATE (C3)
ACETALDEHYDE-TPP $(C 2)$<smiles>O=CO</smiles>
FORMATE $(C 1)$

(C1)

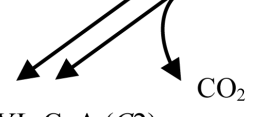

ACETYL-CoA (C2)

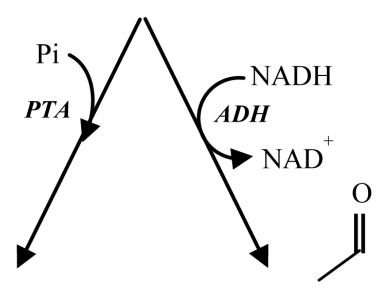

ACETYL-P (C2)

ETHANAL (C2)
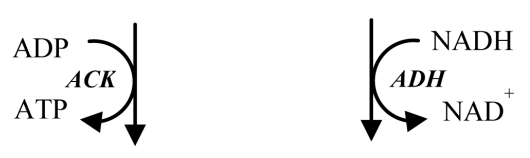<smiles>CC(=O)[O-]</smiles>

ACETATE $(C 2)$<smiles>CCO</smiles>

ETHANOL $(C 2)$
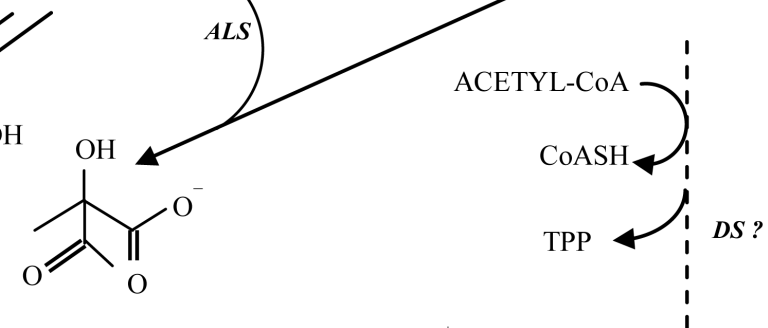<smiles>C=C(C)C(C)O[C@@H](C)C(=O)OC(C)(C)C</smiles>

$\mathrm{O}$

ACETOIN (C4)
(C5)

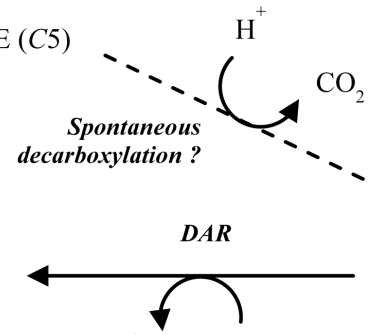

NAD

$\mathrm{NADH}$
$\mathrm{O}$

DIACETYL (C4)

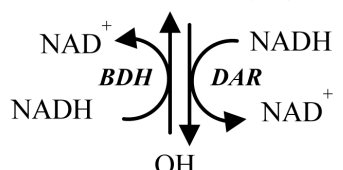<smiles>CC(O)C(C)O</smiles>

2,3 BUTANEDIOL ( $C 4)$

Figure 1. Glucidic and citrate fermentation by the homofermentative citrate positive LAB such as LD. CL: citrate lyase, OAD: oxaloacetate decarboxylase, LDH: lactate dehydrogenase, ALS: $\alpha$-acetolactate synthase, ALD: $\alpha$-acetolactate decarboxylase, DS: diacetyl synthase, DAR: diacetyl/acetoïn reductase, BDH: 2,3-butanediol dehydrogenase, PFL: pyruvate formate lyase, PDHC: pyruvate dehydrogenase complex, PTA: phosphotransacetylase, ACK: acetate kinase, ADH: aldehyde/ alcohol dehydrogenases, TPP: thiamine pyrophosphate CoA: coenzyme A. 


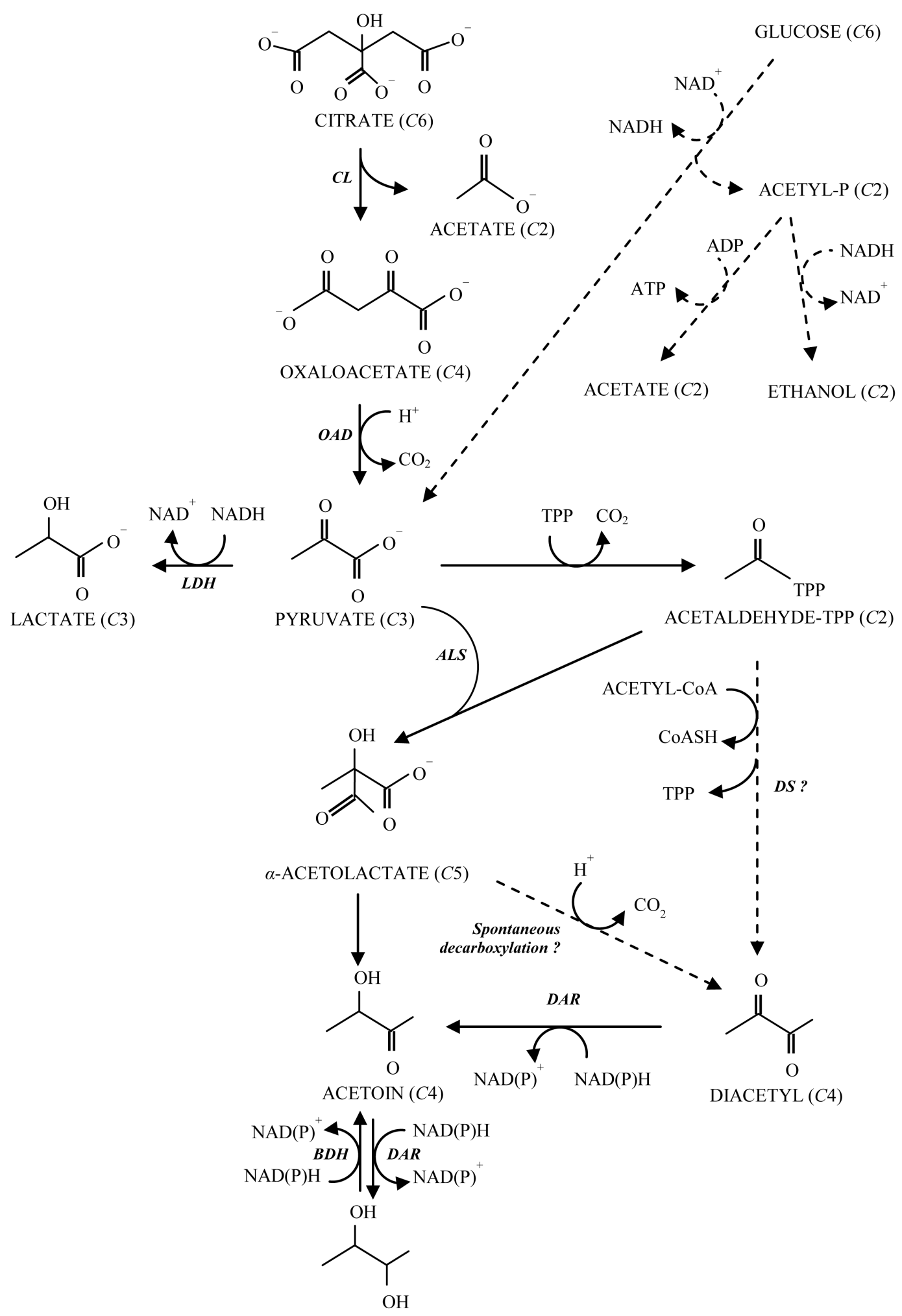

2,3 BUTANEDIOL $(C 4)$

Figure 2. Glucidic and citrate fermentation by the heterofermentative citrate positive inLAB such as cpLN. CL: citrate lyase, OAD: oxaloacetate decarboxylase, LDH: lactate dehydrogenase, ALS: $\alpha$-acetolactate synthase, ALD: $\alpha$-acetolactate decarboxylase, DS: diacetyl synthase, DAR: diacetyl/acetoïn reductase, BDH: 2,3-butanediol dehydrogenase, TPP: thiamine pyrophosphate, CoA: coenzyme A. 
All the genes involved in the uptake and the citrate conversion into pyruvate are plasmidic for cpLN. Studies on Ln paramesenteroides revealed a low level of constitutive transcription of the gene cluster citI-citMCDEFGRP [20]. The transcription of these genes is enhanced by the presence of citrate in the culture medium irrespective of the medium pH [21] (Table 1 [1] [16] [20]-[26] and Table 2 [27] [28]).

For LD, CitP is encoded by the plasmidic citQRP operon, whereas the CL and the oxaloacetate decarboxylase are encoded by the chromosomal citM-citI-citCDEFXG cluster. The genes involved in the citrate transport throughout the cytoplasmic membrane and its consecutive conversion into pyruvate are constitutively expressed [16]. The transcription of the two clusters is activated by acidic conditions [23]. For more details on the regulation of the citrate transport and its fermentation into $\mathrm{C}_{4}$ compounds formation in LAB see the reference [1].

\subsection{Pyruvate Metabolism in Homofermentative LAB}

Pyruvate can then follow three different routes. Pyruvate is a compound common to the glucidic and the citrate pathways. In the presence of sugars, nicotinamide (NAD) cofactors reduced during the Embden-Meyerhof-Parnas pathway (EMP) are reoxidized by lactate dehydrogenase (LDH) to form lactate. The transcription of the gene encoding for LDH is activated by fructose 1,6-diphosphate. The latter is also an allosteric activator of the LDH. Thus, pyruvate is rapidly converted into lactate and NADH is regenerated [7]. For example, the glucose/ citrate co-metabolism in LD leads to the lactate conversion of $80 \%$ of the citrate metabolized [29] (Table 3 [3] [7] [10] [24] [30]-[34]).

Where sugar is limited, LD switches from an homolactic to a mixed acid fermentation. Under strict anaerobic conditions, the pyruvate formate lyase (PFL) converts pyruvate into formate and acetyl-coA. The PFL is inhibited by a $\mathrm{pH}$ inferior to 6 and by two metabolic intermediates of the EMP pathway: glyceraldehyde-3P and dihydroxy-acetone-P [3] [32]. Under strong aerobic conditions, pyruvate is decarboxylated by the pyruvate dehydrogenase complex (PDHC) to give acetyl-CoA, $\mathrm{CO}_{2}$ and an additional reduced nicotinamide cofactor. One subunit of the enzymatic complex is inactivated by NADH; therefore, the PDHC of Lc lactis has a very low activity under anaerobic conditions [3] [35]. The PDHC requires the presence of lipoic acid as a co-factor to be active [36]. Regardless of the enzymes involved in the formation of acetyl-CoA, the activities of phosphotransacetylase (PTA) and acetate kinase (ACK) lead to the release of acetate. This pathway allows one ATP molecule to be produced per acetyl-CoA. Otherwise, aldehyde/alcohol dehydrogenases (ADH) generate acetaldehyde or ethanol, respectively. This pathway allows one NADH molecule to be reoxidized (Table 4 [3] [30] [32] [34]$[40])$.

Supposing citrate to be the sole carbon source, reference [41] recently highlighted another pathway leading to acetate formation without the help of any acetate kinase or ATP formation. This is likely to involve pyruvate oxidase, but this pathway has to be explored further.

\subsection{Pyruvate Metabolism of Heterofermentative LAB}

Concerning heterofermentative $\mathrm{LAB}$, the pentose phosphate pathway leads to four different end-products: $\mathrm{CO}_{2}$, lactate, acetate or ethanol according to the NADH:NAD ratio. In contrast with homofermentative LAB, the mixed acid pathway does not exist for heterofermentative LAB. Acetate and ethanol are produced from the pentose phosphate pathway. Pyruvate arising from citrate leads to the formation of lactate by LDH, with the use of NADH. A low level of NADH leads to acetate and ATP formation but with less ethanol produced from the glucidic source; the citrate acts then as an electron acceptor [8]. Under specific conditions (see below), $\mathrm{C}_{4}$ compounds are produced.

\section{4. $\mathrm{C}_{4}$ Pathway in Homo- and Heterofermentative LAB and the Key Regulation of the Transcription}

Under aerobic and acidic conditions, the citrate/sugar co-metabolism leads to the production of pyruvate in excess; this is explained by the lower activity or the inactivation of the enzymes involved in pyruvate conversion. The increase in pyruvate concentration leads to a growth in pyruvate flux towards the $\mathrm{C}_{4}$ pathway. In the presence of thiamin pyrophosphate (TPP), the pyruvate is decarboxylated to form $\mathrm{CO}_{2}$ and acetaldehyde thiamine pyrophosphate (active acetaldehyde). The $\alpha$-acetolactate synthase (ALS) condenses the latter with a second molecule of pyruvate, yielding one mole of $\alpha$-acetolactate (AL). For LD and cpLN, ALS is constitutively expressed 
Table 1. Genes localization and transcription type of gene clusters implied in the first steps of citrate metabolism in LD and cpLN.

\begin{tabular}{|c|c|c|}
\hline \multirow{2}{*}{$\begin{array}{l}\text { Transporter or } \\
\text { enzymes }\end{array}$} & \multicolumn{2}{|c|}{ Microorganisms } \\
\hline & $\mathrm{LD}^{\mathrm{a}}$ & cpLN \\
\hline CitP & $\begin{array}{c}\text { citQRP operon harboured by a } 8 \text { kb plasmid, } \\
\text { Constituvely expressed and enhanced under acidic } \\
\text { conditions (pH 4.5) [16] [22] [23]. }\end{array}$ & $\begin{array}{l}\text { citI-citMCDEFGRP cluster harboured by a } 22 \mathrm{~kb} \\
\text { plasmid, } \\
\text { Low constitutive transcription, enhanced by citrate } \\
\text { addition [20] [21]. }\end{array}$ \\
\hline $\begin{array}{l}\text { CL and } \\
\text { OAD }\end{array}$ & $\begin{array}{c}\text { Chromosomal citM-citI-citCDEFXG cluster, } \\
\text { Constitutively expressed, and enhanced under acidic } \\
\text { conditions (pH } 4.5 \text { to 5) [1] [16] [24] [25]. }\end{array}$ & \\
\hline
\end{tabular}

${ }^{\mathrm{a}}$ A few atypical citrate-positive Lactococcus strains harboured a plasmid with citI-citMCDEFGRP cluster [26].

Table 2. Activators and characteristics of CitP in LD and cpLN.

\begin{tabular}{ccc}
\hline CitP & LD & Microorganisms \\
\cline { 2 - 2 } $\begin{array}{c}\text { Activating factors/ } \\
\text { optimal activity parameters }\end{array}$ & Activators: $\mathrm{Cu}^{2+}$ and $\mathrm{Co}^{2+}[27]$. & Optimum pH for Ln lactis: 6 [28]. \\
\hline
\end{tabular}

Table 3. Genes localization, transcription type, activators, inhibitors and characteristics of LDH implied in glucidic and citrate metabolism in LD and cpLN.

\begin{tabular}{|c|c|c|}
\hline \multirow{2}{*}{$\mathrm{LDH}$} & \multicolumn{2}{|c|}{ Microorganisms } \\
\hline & LD & cpLN \\
\hline Genes localization & Chromosomic genes [30]. & Chromosomic genes [31]. \\
\hline $\begin{array}{l}\text { Activating factors/ } \\
\text { optimal activity } \\
\text { parameters }\end{array}$ & $\begin{array}{c}\text { Activators: fructose-1,6-diphosphate (FDP) } \\
\text { (transcriptional and allosteric activation) and NADH } \\
\text { [7], Carbon source: glucose, lactose, } \\
\text { Sugar in excess [32]. }\end{array}$ & $\begin{array}{l}\text { No activators found-no regulation found [3] [33], } \\
\text { Optimal pH for Ln lactis: } 7.5 \text { [24]. }\end{array}$ \\
\hline Inhibitory factors & $\begin{array}{c}\text { Oxygen which is associated to a lower FDP } \\
\text { concentration [32], phosphoenolpyruvate (PEP) and } \\
\text { inorganic phosphates [10], } \\
\text { Sugar-limited conditions, high aeration, } \\
\text { Low NADH/NAD ratio (inferior to 0.03) and } \\
\text { inorganic phosphate [34]. }\end{array}$ & pH inferior to 5 [33]. \\
\hline $\begin{array}{l}\text { Enzymes } \\
\text { characteristics }^{\mathrm{a}}\end{array}$ & $\begin{array}{c}\text { Specific activity of } 0.0043 \mathrm{U} / \mathrm{mg} \text {, } \\
\text { Michaelis constant (Km) for pyruvate: } 3 \mathrm{mM} \text { at pH } \\
7.2[34] \text {. }\end{array}$ & $\begin{array}{l}\text { For Ln lactis, the kinetic parameters decrease as the } \mathrm{pH} \\
\text { decreases: the Km for NADH, pyruvate, and the Vmax } \\
\text { decrease } 30-\text {, } 20 \text { - and } 8 \text {-fold respectively as the } \mathrm{pH} \\
\text { decreases from } 8 \text { to } 5 \text { [33], } \\
\text { For Ln lactis: } \\
\text { Km for NADH are } 0.307 \text { and } 0.023 \mathrm{mM} \text { at } \mathrm{pH} 7 \text { and } 5 \\
\text { respectively, } \\
\text { Km for pyruvate are } 1.23 \text { and } 0.062 \mathrm{mM} \text { at pH } 7 \text { and } 5 \\
\text { respectively [33], } \\
\text { Km for pyruvate: } 1.05,0.25 \text { and } 0.13 \mathrm{mM} \text { at pH values of } \\
7.5,6.5 \text { and } 5.0 \text { respectively [24], } \\
\text { The optimum pH decreases as the level of pyruvate } \\
\text { decreases [33]. } \\
\text { For Ln mesenteroides subsp. cremoris: } \\
\text { Km for pyruvate: } 0.3 \mathrm{mM} \text {, } \\
\text { Km for NADH: } 0.03 \mathrm{mM} \text { [31]. }\end{array}$ \\
\hline
\end{tabular}

${ }^{\mathrm{a}}$ Some of these characteristics are given for specific environmental factors and for specific analytical methods, for more details, refer to the relevant article. 
Table 4. Genes localization, transcription type, activators, inhibitors and characteristics of PFL and PDHC implied in glucidic and citrate metabolism in LD.

\begin{tabular}{|c|c|c|}
\hline \multirow{2}{*}{ In LD } & \multicolumn{2}{|c|}{ Enzymes } \\
\hline & PFL & PDHC \\
\hline Genes localization & Chromosomic genes [30]. & Chromosomic genes [30]. \\
\hline $\begin{array}{l}\text { Activating factors/ } \\
\text { optimal activity } \\
\text { parameters }\end{array}$ & $\begin{array}{l}\text { Anaerobic conditions, } \\
\text { Optimal pH: superior to } 7 \text { [32], } \\
\text { Carbon source: galactose [37]. }\end{array}$ & $\begin{array}{c}\text { Oxygen [3], } \\
\text { Lactose limitation [40], } \\
\text { pH optimum: } 5.5 \text { - } 6.5 \text { [32]. }\end{array}$ \\
\hline Inhibitory factors & $\begin{array}{l}\text { Oxygen [3] [32] [39], } \\
\text { pH inferior to } 6 \text { [3], } \\
\text { Triose phosphates as glyceraldehyde-3-phosphate } \\
\text { and dihydroxyacetone phosphate [34] [38] [39]. }\end{array}$ & $\begin{array}{c}\text { NADH, } \\
\text { Anaerobic condition [35]. }\end{array}$ \\
\hline $\begin{array}{c}\text { Enzymes } \\
\text { characteristics }^{\mathrm{a}}\end{array}$ & Km for pyruvate: 1 mM at pH 7.2 [34]. & $\begin{array}{l}\text { Enzyme requires to be functional: lipoic acid, divalent } \\
\text { cations, thiamine pyrophosphate (TPP) and CoA [35] [36], } \\
\text { Specific activity: } 6.5 \mathrm{U} / \mathrm{mg} \text {, } \\
\text { Km for pyruvate: } 1 \mathrm{mM} \text {, } \\
\text { Km for TPP: } 3.2 \mu \mathrm{M} \text { [35]. }\end{array}$ \\
\hline
\end{tabular}

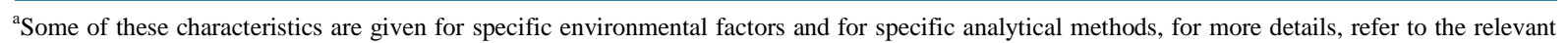
article.

at low concentration and partially induced in an acidic environment-around pH 5-and in the presence of citrate [24] [35]. The optimal pH of ALS is around 5.5 for LD and cpLN [25] [28] (Table 5 [1] [3] [8] [24] [25] [28] [30] [35] [42]-[46]).

The ALS of cpLN has a lower Michaelis constant for pyruvate (Km: $10 \mathrm{mM}$ ) than that of LD (Km: $50 \mathrm{mM})$ [35] [42]. A high Km value for pyruvate favors the elimination of this toxic metabolite without there being any competition between the ALS and the enzymes involved in the pyruvate catabolism. And, the ALS of LD shows a higher activity than that of cpLN with $80 \mathrm{mM}$ of pyruvate [45]. There are two groups of ALS which present a high amino acid homology. One is involved in the biosynthesis of the branched-chain amino acids (BCAA) leucine, valine and isoleucine (and frequently named acetohydroxyl acid synthase, AHAS), and the other in the catabolic pathway of pyruvate [1]. The anabolic AHAS has an optimum pH of 8.0, requires flavin adenine dinucleotide (FAD) and $\mathrm{MgCl}_{2}$ and is subjected to a negative feedback control by BCAA. The catabolic ALS does not need these co-factors and optimally works at pH 6.0 [42] [46]. These two enzymes lead to $\alpha$-acetolactate (AL) formation. As the AHAS is inhibited by a lot of herbicides (for a review, see [47]), we can suppose-even if no information has been published to confirm it - that the ALS activity is also depleted by the same types of inhibitors. The anabolic AHAS has been detected in Lc lactis but not in Leuconostoc spp.

AL is then decarboxylated into acetoin by the $\alpha$-acetolactate decarboxylase (ALD). In the specific case of LD, this conversion is modulated by different factors, among them the BCAA metabolism [42]. Compared with wild strains, dairy Lactococcus strains have lost the ability to synthesize these amino acids. From an evolutionary point of view, this loss could be explained by the transfer of the microorganisms from their poor primary ecological niche-vegetable leaves - to a richer one, the milk; these functions would have then become superfluous [48] [49]. As indicated above, AL is decarboxylated into acetoin by the ALD. Consequently, in the "prototrophic” wild LD evolving in an oligotrophic environment, the ALD plays a dual role in the cell: either the AL flux is orientated towards the BCAA pathway, or it is transformed into $\mathrm{C}_{4}$ compounds. Consequently, the expression of the ALD is strictly regulated at both transcriptional and post-transcriptional levels [1]. In addition, ALD is allosterically activated by leucine. In spite of the incapacity of the dairy Lactococcus strains to synthesize BCAA, the ALD activation by these amino acids is conserved [45]. The gene encoding the ALD of LD seems to be constitutively expressed, in accordance with the basal transcription level of the ALS [50] (Table 6 [1] [8] [24] [25] [30] [45] [50]).

In the presence of oxygen, AL is also spontaneously decarboxylated into diacetyl. However, other enzymatic pathways involving cofactors or ALD might lead to diacetyl formation [51]-[53]. At the present time, this remains a supposition.

The diacetyl/acetoin reductase (DAR) catalyzes the acetoin reduction into 2,3-butanediol and the diacetyl reduction into acetoin. This latter reaction is irreversible whereas 2,3-butanediol can be reoxidized into acetoin by 
Table 5. Genes localization, transcription type, activators, inhibitors and characteristics of ALS in LD and cpLN.

\begin{tabular}{|c|c|c|}
\hline \multirow{2}{*}{ ALS } & \multicolumn{2}{|c|}{ Microorganisms } \\
\hline & LD & cpLN \\
\hline $\begin{array}{l}\text { Genes } \\
\text { localizationand } \\
\text { transcription type }\end{array}$ & $\begin{array}{c}\text { Chromosomic genes, constitutively expressed, } \\
\text { enhanced under acidic conditions (pH 5) and } \\
\text { partially induced by the presence of citrate [1] [24] } \\
\text { [25] [30]. }\end{array}$ & $\begin{array}{l}\text { Chromosomic genes, low constitutive transcription, } \\
\text { partially induced by citrate addition, enhanced under } \\
\text { aerobic conditions and sugar-limited source [8] [28] [42]. }\end{array}$ \\
\hline $\begin{array}{c}\text { Activating } \\
\text { factors/optimal } \\
\text { activity parameters }\end{array}$ & $\begin{array}{l}\text { Oxygen [43] [44], } \\
\text { Optimum pH: } 5.5-6 \text { and } 60 \% \text { of the maximum } \\
\text { activity at } \mathrm{pH} 6.5 \text { [35] [45]. }\end{array}$ & $\begin{array}{l}\text { Optimum pH for } L n \text { lactis: between } 5 \text { and } 6 \text { [28] [42] [45], } \\
\text { Optimum pH for Ln mesenteroides subsp. mesenteroides } \\
\text { and Ln mesenteroides subsp. cremoris: } 5.1-5.3 \text { and 20\% } \\
\text { of the maximal activity at pH } 6.5 \text { [42] [46]. }\end{array}$ \\
\hline Inhibitory factors & - & $\begin{array}{l}\text { ALS of Ln lactis and Ln mesenteroirdes subsp. cremoris is } \\
\text { inhibited by several intermediates of glucose metabolism } \\
\text { [42] [46]. }\end{array}$ \\
\hline $\begin{array}{c}\text { Enzymes } \\
\text { characteristics }^{\mathrm{a}}\end{array}$ & $\begin{array}{l}\text { Enzyme requires to be functional: divalent cations } \\
\text { and TPP [3], } \\
\text { Specific activity: } 103 \mathrm{U} / \mathrm{mg} \text {, } \\
\text { Km for pyruvate: } 50 \mathrm{mM} \text {, } \\
\text { Km for TPP: } 3.2 \mu \mathrm{M} \text { [35], } \\
\text { Specific activity: ranged from } 0.1 \text { to } 0.38 \mathrm{U} / \mathrm{mg} \text { for } 4 \\
\text { strains of LD with } 80 \mathrm{mM} \text { of pyruvate, } \\
\text { Km for pyruvate: } 30 \mathrm{mM} \text { [45]. }\end{array}$ & $\begin{array}{l}\text { Enzyme requires to be functional: } \\
\text { divalent cations and TPP [3], } \\
\text { Km for pyruvate for } L n \text { mesenteroirdes subsp. cremoris: } \\
\qquad 10 \mathrm{mM} \text { [42], } \\
\text { For Ln lactis, Ln mesenteroides subsp. mesenteroides and } \\
\text { Ln mesenteroides subsp. cremoris: } \\
\text { Specific activity: ranged from } 0.018 \text { and } 0.219 \mathrm{U} / \mathrm{mg} \text { with } \\
\quad 80 \mathrm{mM} \text { of pyruvate, } \\
\text { Km for pyruvate: } 10 \mathrm{mM}[45] \text {. }\end{array}$ \\
\hline
\end{tabular}

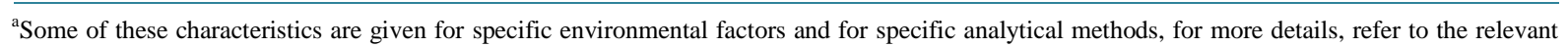
article.

Table 6. Genes localization, transcription type, activators, inhibitors and characteristics of ALD in LD and cpLN.

\begin{tabular}{|c|c|c|}
\hline \multirow{2}{*}{ ALD } & \multicolumn{2}{|c|}{ Microorganisms } \\
\hline & LD & cpLN \\
\hline $\begin{array}{l}\text { Genes } \\
\text { localizationand } \\
\text { transcription type }\end{array}$ & $\begin{array}{l}\text { Chromosomic genes, constitutively expressed, and } \\
\text { enhanced under acidic conditions (pH 5) [1] [25] } \\
\text { [30] [50]. }\end{array}$ & Chromosomic genes [8]. \\
\hline $\begin{array}{l}\text { Activating } \\
\text { factors/optimal } \\
\text { activity parameters }\end{array}$ & $\begin{array}{c}\text { pH optimum: } 5.5 \text { and } 60 \% \text { of maximum of activity at } \\
\text { pH } 6.5 \text { [45], } \\
\text { Activation by leucine, isoleucine, valine and notably } \\
\text { allosteric leucine activation [45] [50]. }\end{array}$ & $\begin{array}{c}\text { Optimum pH for Ln lactis: } 5.4 \text { - } 6 \text { [24] [45], } \\
\text { Optimum pH for Ln mesenteroides subsp. mesenteroides } \\
\text { and } L n \text { mesenteroides subsp. cremoris: } 5.1 \text { and } 20 \% \text { of the } \\
\text { maximal activity at pH } 6.5 \text { [45]. }\end{array}$ \\
\hline Inhibitory factors & - & - \\
\hline $\begin{array}{c}\text { Enzymes } \\
\text { characteristics }^{\mathrm{a}}\end{array}$ & $\begin{array}{c}\text { Specific activity: ranged from } 0.058 \text { to } 0.2 \mathrm{U} / \mathrm{mg} \text { for } \\
4 \text { strains of LD with } 48.4 \mathrm{mM} \text { of } \mathrm{AL} \text {, } \\
\text { Km for AL: } 60 \mathrm{mM} \text { [45]. }\end{array}$ & $\begin{array}{c}\text { For Ln lactis, Ln mesenteroides subsp. mesenteroides and } \\
\text { Ln mesenteroides subsp. cremoris: } \\
\text { Specific activity ranged from } 0.109 \text { to } 0.95 \mathrm{U} / \mathrm{mg} \\
\text { with } 3.6 \mathrm{mM} \text { of AL, } \\
\text { Km for AL: } 0.03 \mathrm{mM}[45] .\end{array}$ \\
\hline
\end{tabular}

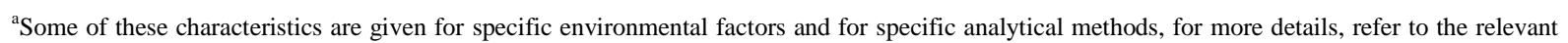
article.

butanediol dehydrogenase (BDH). The LD strains possess one or two enzymes displaying both DAR and BDH activities in the presence of the co-enzyme NAD [54]. In Ln pseudomesenteroides, the same enzyme is involved in the DAR and BDH activities. The diacetyl reductase and the BDH require NADH and $\mathrm{NAD}^{+}$as cofactors, respectively, whereas the acetoin reductase activity can either rely on NADH or NADPH. However, the diacetyl and acetoin reductase activities of Leuconostoc lactis occur only with NADPH as a co-factor [28]. Whereas the reductive activity is optimal under slightly acidic conditions-between $\mathrm{pH} 5.2$ to 6.6-the oxidative activity is optimal in an alkalinized environment, that is between $\mathrm{pH} 7.5$ to 10 [54]. Under acidic conditions, acetoin and diacetyl compete for the enzyme, though the DAR has a lower Km for acetoin (Km: 0.2 and $0.3 \mathrm{mM}$ for LD and cpLN, respectively) than for diacetyl (Km: 9.0 and $5.1 \mathrm{mM}$ for LD and cpLN, respectively). These Km values might indicate that the DAR activity would become vigorous as soon as the diacetyl concentration reaches a 
toxic level for the cells [55]. Acetoin exerts an inhibitory effect on the acetoin reductase activity if its concentration exceeds $1 \mathrm{mM}$ [3]. When the $\mathrm{pH}$, the growth temperature and the storage temperature diminish to $4.5,18^{\circ} \mathrm{C}$ and between $2^{\circ} \mathrm{C}$ and $5{ }^{\circ} \mathrm{C}$, respectively, the reductase activity of the DAR is strongly inhibited in cpLN and LD cells; the diacetyl pool is favored [24] [56]-[59]. The gene encoding for the DAR/BDH is carried on the chromosome in Lc lactis whereas in Ln pseudomesenteroides, this enzyme seems to be plasmid-encoded [60] (Table 7 [1] [24] [25] [28] [30] [54] [55] [60]).

\section{Part 2 Selective Advantages of the Citrate Metabolism in a Complex Bacterial Ecosystem}

\subsection{Energetic States of LAB from a Bioenergetic Perspective}

As any leaving systems, the bacterial metabolism needs energy to function. Energy can be used for chemical reactions, to allow the cell to move or to translocate molecules inside or outside the membrane. Energy can come from two sources, the degradation of organic molecules, for instance via fermentation, and the electrochemical energy created by an ion gradient (proton in LAB) known as PMF. Energy is "stored" in the energy-rich phosphate-bond intermediates such as ATP or used directly. In LAB, fermentation is much less efficient in yielding ATP than sugar oxidation in aerobic microorganisms - 2 moles of ATP/mole of glucose for homolactic fermentation versus 38 moles of ATP/mole of glucose. The metabolic energy obtained from fermentation is usually insufficient for the energy-requiring processes to operate in the cells [19]. Energy originating from ion gradients is thus essential. The PMF is an electrochemical gradient across the membrane involving two components, a membrane potential (inside negative) and a $\mathrm{pH}$ gradient (inside alkaline for LAB). Two systems can generate a PMF: the "primary" and the "secondary" transport systems. In the primary system, the translocation of ions through the cytoplasmic membrane is coupled with the energy release as a consequence of a chemical or redox reaction; to give an example, we can cite the respiratory chain and the membrane bond F0-F1-ATPase. But generally, fermentative bacteria do not possess the proton pumping electron transfer system, except for some LAB genetically equipped for respiratory metabolism, for example, Lc lactis, Lc garviae, Ln mesenteroides, Weissella paramesenteroides, Enterocococcus faecalis, (for a review see [61]. In fermentative bacteria, the PMF is usually generated via the "secondary" transport system. This system converts the (electro)-chemical energy of one solute into the (electro)-chemical energy of another solute (chemo-chemical coupling). The secondary transport system refers to uniporters catalyzing the translocation of one solute across the cytoplasmic membrane, symporters catalyzing the translocation of two or more solutes in the same direction and antiporters catalyzing the exchange of two molecules in the opposite direction.

Table 7. Genes localization, transcription type, activators, inhibitors and characteristics of DAR/BDH in LD and cpLN.

\begin{tabular}{|c|c|c|}
\hline \multirow{2}{*}{ DAR/BDH } & \multicolumn{2}{|c|}{ Microorganisms } \\
\hline & LD & cpLN \\
\hline $\begin{array}{l}\text { Genes } \\
\text { localizationand } \\
\text { transcription type }\end{array}$ & $\begin{array}{l}\text { Chromosomic genes, enhanced under acidic conditions } \\
\text { (pH 5) and partially repressed by the presence of citrate } \\
\text { [1] [24] [25] [30]. }\end{array}$ & $\begin{array}{l}\text { Plasmidic genes for } L n \text { pseudomesenteroides [60], } \\
\text { Ln lactis: low constitutive transcription partially } \\
\text { repressed by citrate addition [28]. }\end{array}$ \\
\hline $\begin{array}{l}\text { Activating factors/ } \\
\text { optimal activity } \\
\text { parameters }\end{array}$ & $\begin{array}{c}\text { Optimum pH for the reduction of diacetyl: } \\
\text { between } 5.8 \text { and 6.1, } \\
\text { Optimum pH for the oxidation of 2,3-butanediol: between } \\
8.5 \text { and } 10 \text { [54]. }\end{array}$ & $\begin{array}{l}\text { Optimal pH for } L n \text { lactis: } 5.7 \text { [28], } \\
\text { Optimal pH for } L n \text { pseudomesenteroides: } 5.5 \text { for the } \\
\text { reductive activity and } 7.5 \text { for the oxidative activity, } \\
\text { Optimal temperature for } L n \text { pseudomesenteroides: } \\
\quad 40^{\circ} \mathrm{C} \text {, and active from } 20^{\circ} \mathrm{C} \text { to } 55^{\circ} \mathrm{C} \text { [55]. }\end{array}$ \\
\hline Inhibitory factors & $\mathrm{pH}$ of 4.5 [54]. & - \\
\hline $\begin{array}{c}\text { Enzymes } \\
\text { characteristics }^{\mathrm{a}}\end{array}$ & $\begin{array}{l}\text { The diacetyl reductase activity is } 7 \text { - and } 4.7 \text {-fold higher } \\
\text { (for the two DAR) than the acetoin reductase activity with } \\
10 \mathrm{mM} \text { of substrate. } \\
\text { When the two substrates are present, acetoin is the } \\
\text { preferred substrate for the two DAR [54]. } \\
\text { Km for diacetyl: } 9 \mathrm{mM} \text {, } \\
\text { Km for acetoin: } 0,2 \mathrm{mM} \text {, } \\
\text { Acetoin acts as inhibitor at concentrations above } 1 \mathrm{mM} \\
\text { [3], Coenzyme: specific for NADH [28]. }\end{array}$ & $\begin{array}{l}\text { Km for diacetyl, acetoin and meso-2,3-butanediol for } \\
\text { Ln pseudomesenteroides: 5.1, 0.34 and 1.67 mM at pH } \\
\text { 5.5, 5.5 and 7.5; respectively [55]. } \\
\text { Coenzyme: Ln lactis: specific for NADPH [28], } \\
\text { Ln pseudomesenteroides: diacetyl reductase requires } \\
\text { only NADH as coenzyme for the diacetyl reduction } \\
\text { and either NADH or NADPH for the acetoin } \\
\text { reduction. The enzyme catalyzes the oxidation of } \\
\text { meso-2,3-butanediol only with the NAD } \text { [55]. }^{+} \text {[55 }\end{array}$ \\
\hline
\end{tabular}

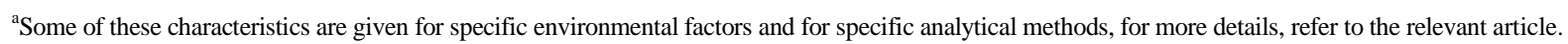


In $\mathrm{LAB}$, a PMF can be generated by the fermentation of citrate for instance. The CitP is a secondary active transport system which allows the translocation of substrates with $\mathrm{R}_{1} \mathrm{R}_{2} \mathrm{C}(\mathrm{OH}) \mathrm{COOH}$ motif-citrate, malate, lactate, OxA-inside the cell [41] [62]. In the presence of lactate, which can originate from the citrate/sugar co-metabolism, the citrate is internalized inside the cell concomitantly with the externalization of lactate. This Hcitrate $^{2-}$ /lactate ${ }^{-}$antiport generates an electrical potential across the membrane $(\Delta \Psi)$ and the internalization of one electron per pair of molecules translocated. In the absence of lactate, the symport Hcitrate ${ }^{2-} / \mathrm{H}^{+}$occurs with the same consequence on the membrane potential, namely the translocation of one negative charge into the cell. Moreover, the subsequent steps of the citrate catabolism lead to proton consumption as well. This depletion participates in the generation of the PMF which then results both from an electrical and a chemical potential of electrons $(\Delta \mathrm{pH})$ across the membrane [62]. Thus, the citrate metabolism can be considered as a PMF-generating system resulting from the action of the CitP secondary active transporter and the proton consumption in the cytoplasm. Overall, this leads to the alkalization of the inner part of the cell. The term "secondary PMF-generating pathway" is frequently used to refer to the citrate metabolism [16].

Besides its energy supplier function, the PMF system allows the LAB to better withstand sugar starvation. Indeed, LAB can encounter drastic fluctuations in the composition of their environment. As a consequence of carbon source depletion, the ATP rate generated by glycolysis can decrease rapidly. The PMF system, active for several hours (as long as $24 \mathrm{~h}$ in certain cases), enables the bacteria to survive by maintaining the energy pool inside the cell [19] [63]. Therefore, the citrate metabolism provides a growth advantage to citrate positive LAB.

\subsection{Acidic Stress Resistance}

During the fermentation step, organic acids are produced-mainly lactic and acetic acids-lowering the $\mathrm{pH}$ of the medium. The proportion of acid-protonated forms $[\mathrm{AH}]$ outside the cell increases as the $\mathrm{pH}$ decreases, whereas the dissociated form of acids [ $\left.\mathrm{A}^{-}\right]$diminishes. This evolution depends on the $\mathrm{pK}_{\mathrm{A}}$ of each acid. Un-dissociated $[\mathrm{AH}]$ forms passively cross the cytoplasmic membrane, i.e. without any energy requirement. Inside the cells, the $\mathrm{pH}$ is generally close to neutrality (between 6 and 7). Consequently, $[\mathrm{AH}]$ dissociate to form $\left[\mathrm{A}^{-}\right]$with the concomitant release of a proton $\left[\mathrm{H}^{+}\right]$and an electron which contribute both to acidify the cytoplasm; this can compromise the $\mathrm{pH}$ homeostasis. The cell has to prevent $\left[\mathrm{A}^{-}\right]$accumulation by rejecting it outside and to stabilize its internal $\mathrm{pH}$. This requires energy. Weak acids and low external $\mathrm{pH}$ have synergic deleterious effects on cell viability. As the acidification progresses, the preservation of an active metabolism becomes more and more difficult. The increasing need for energy is supplied by the carbon metabolism, which generates growing quantities of organic acids. In the absence of $\mathrm{pH}$ buffering or medium regeneration, this deadly circle leads to the progressive poisoning of the cell. The population growth finally stops or the population may even begin to decrease.

In $\mathrm{LD}$, the citrate metabolism pathway is constitutively expressed and enhanced under acidic conditions, i.e. during the late exponential growth phase. Moreover, acidic conditions- $\mathrm{pH} 5$ or below-favor the activity of several enzymes, ALS, ALD and DAR for example, and the transport activity of the CitP system (optimal pH between 4.5 and 5.5) [1] [22]. The citrate metabolism is all the more protective as the lactate toxicity is the most deleterious; cells are thus more resistant at low $\mathrm{pH}$ [16].

In the subsequent steps of the citrate fermentation pathway, the decarboxylations of OxA and AL are both proton-consumers. Each citrate molecule catabolized leads then to the "consumption" of two scalar protons; this contributes to the cytoplasm alkalization. Hence, the citrate metabolism plays an important role in the regulation of the intracellular $\mathrm{pH}$ homeostasis necessary for the maintenance of metabolic activities and growth. This effect is extended by the related release of neutral compounds, ethanol, $\mathrm{CO}_{2}$, acetoin, diacetyl and 2,3-butanediol. A moderate re-alkalization of the culture medium is then observed [18] [64] [65]. This re-alkalization seems to improve the efficiency of the use of citrate and the sugar metabolism [22].

These additional benefits of citrate metabolism could explain the growth stimulation of LD observed when citrate is added to the medium (even if this activation remains marginal compared to that of cpLN). Indeed, the specific growth rate increases from $10 \%$ to $15 \%$ for LD after citrate addition, and from $50 \%$ to $100 \%$ for cpLN [64] [66]-[68]. As for the heterofermentative bacteria, the citrate/glucid co-metabolism also improves the acid resistance at low $\mathrm{pH}$ and participates in the energetic metabolism of the cell; but the key regulators of the citrate metabolism are different (see below).

\subsection{Effects on Growth}

In cpLN, the transcription gene coding for the CitP and the two enzymes involved in the first steps of citrate de- 
gradation into pyruvate (CL, OAD) are induced by the presence of citrate regardless of the external $\mathrm{pH}$. In the absence of substrate, CitP, CL and OAD are only present at low basal levels [20] [21]. This is contrary to LD, where the transporter and the enzymes CL and OAD are constitutively expressed and the transcription of the gene cluster is greatly improved under acidic $\mathrm{pH}$ [16]. Thus in $\mathrm{cpLN}$, the citrate is co-metabolized with a glucidic source during the exponential growth phase. The heterolactic fermentation of sugars leads to the formation of $\mathrm{CO}_{2}$, lactate and acetate or ethanol depending on the $\mathrm{NADH}: \mathrm{NAD}^{+}$ratio. When glucose is the unique source of carbon, a high $\mathrm{NADH}: \mathrm{NAD}^{+}$ratio favors the formation of ethanol concomitantly with the regeneration of $\mathrm{NAD}^{+}$. In the case of a citrate/glucid co-metabolism, the initial steps lead to pyruvate formation without any NADH. Moreover, the LDH of cpLN under neutral or slightly acidic conditions (above $\mathrm{pH}$ 5) is not subject to any regulation; all the pyruvate is therefore converted into lactate with the concomitant re-oxidation of NADH. Consequently, there is a lack of NADH (or any other reduced molecule) to reduce the acetyl-P formed in the pentose phosphate pathway. Instead of ethanol, acetate is generated. This pathway is energetic. As a result, the maximum specific growth rate greatly increases. The growth yield, i.e. biomass produced per mole of metabolized sugar, is also improved, even if it depends on the strains and the physico-chemical conditions [17] [66]. The same observations have been made for LD under acidic conditions with the citrate/sugar co-metabolism [18].

\subsection{Biopreservation}

During the citrate/glucose co-metabolism of cpLN, the lactate production is 1.63 fold higher when citrate concentration varies from 0 to $25 \mathrm{mM}$, although the level of the LDH is divided by about 3 [69]. The citrate/glucose co-metabolism also leads to a better utilization of glucose by cpLN and LD and so to greater lactate excretion [22]. Lactate is usually considered as a food preservative for its antimicrobial activities. Several mechanisms of inhibition have been proposed. Lactate, like many organic acids, has the ability to cross the cell membrane passively in its un-dissociated form; thereafter, it dissociates inside the cell into two parts, a salt and a proton. The proton lowers the inner $\mathrm{pH}$. This mechanism has been described above in this article. Even if the $\mathrm{pK}_{\mathrm{A}}$ value of lactate is lower compared with that of acetate and propionate-3.86, 4.73, and 4.87, respectively-lactate is a more efficient inhibitor compared with other organic acids at identical concentrations [70]. A higher lactate concentration is then supposed to deplete the other microflora and among them, the undesired microbes, pathogens and spoiling cells.

At high concentrations, lactate is also known to lower the water activity by sequestering a part of the water available in the medium. Other specific inhibitory effects have been suggested. Organic acids are able to chelate cations, which render them inaccessible to support the growth of some microorganisms; this is the case for Listeria monocytogenes. Although this inhibition mechanism is globally understood, further studies have to be made for its complete deciphering and the implications on the bacteriostatic effects [71].

Moreover, citrate metabolism systematically leads to acetate formation, in particular as a result of the action of the CL. This release is observed whatever the metabolism, homo- or heterofermentative, of LAB. In a complex microbial ecosystem, the other microorganisms are thus subjected to the synergestic inhibitory effects of these organic acids produced in a more and more acidic environment [72].

At low $\mathrm{pH}-5$ and below-the apparent $\mathrm{Km}$ value of the cpLN LDH tends to decrease. More pyruvate is available for the $\mathrm{C}_{4}$ compounds formation pathway as a consequence of the saturation of the LDH [24]. In the case of LD, anaerobic and acidic conditions inhibit the mixed acid fermentation pathway and the pyruvate coming from the citrate/glucid co-metabolism is produced in excess. The toxic pyruvate is converted by the ALS into AL. Under aerobic conditions, this compound is decarboxylated into diacetyl. Diacetyl has a broad antimicrobial spectrum. For instance, the Gram negative bacteria and yeasts are inhibited at $200 \mathrm{ppm}$ and the Gram positive non-lactic acid bacteria at $300 \mathrm{ppm}$ of diacetyl [73]. According to reference [74], most of the LAB is not affected by concentrations ranging between 100 to $350 \mathrm{ppm}$. But, our results obtained with two strains of $L c$ lactis subsp lactis and one Lc lactis subsp cremoris suggested a significant effect at a $100 \mathrm{ppm}$ concentration. However, the diacetyl concentration detected in fermented food matrices is not so high, around $2 \mathrm{ppm}$ in wine and $5 \mathrm{ppm}$ in dairy products [5] [75]. These rates have no visible effect on the Lactococcus growth compared with the control samples [76]. Diacetyl could, however, act synergistically with other factors and is, besides, an unstable compound [77]. Being volatile and influenced by the medium composition, diacetyl concentration can vary a lot and could be under-estimated. The accuracy of the published results is also debatable if we consider the different methods of diacetyl extraction and quantification used [78] [79]. For example, according to refer- 
ence [80], the diacetyl concentration in fermented raw milk ranges between 48 to $133 \mathrm{ppm}$. This concentration could then have an inhibitory effect on LAB and other microflora.

\subsection{Observation of the Selective Advantage of Citrate Metabolism in a Complex Bacterial Ecosystem}

As a consequence of those four points, we can imagine that in complex ecosystems, citrate positive lactic acid bacteria are favored. In the same way, reference [81] highlights an antagonistic effect of citrate positive facultative heterofermentative lactobacilli towards citrate negative propionic acid bacteria in hard Swiss-type cheese. This could explain the observations we made when we cultured together a mix of four lactococci in milk. One strain was a LD. After clotting, the curd was removed and the whey used to re-seed the following day's milk. This is called "backslopping". This procedure was followed during 10 consecutive days. From day to day, we observed the progressive dominance of the LD strain. After 8 days, only LD was detected on Petri dishes [76]. We also observed the composition of the dominant LAB populations in a natural whey starter used to make Rocamadour cheeses during four months (Demarigny, personal communication). The same result was found. Progressively, the LD population overwhelmed the other lactococci. And consequently, the organoleptic characteristics of the cheeses were altered.

As noticed above for LD, we can argue that this metabolism allows the cpLN to take advantage over the other microflora. Recently, we indicated that many naturally fermented tropical vegetable products were characterized by the systematic presence of lactobacilli together with leuconostocs [82]. Among the different hypotheses put forward, we proposed that the energetic metabolism of cpLN gave them a selective advantage to settle even under harsh conditions-low $\mathrm{pH}$, the presence of many other microorganisms.

\section{Conclusion}

The LAB citrate metabolism has been extensively studied, especially during the nineties. Although many articles have been published on this subject, to our knowledge, they generally tended to have biochemical objectives, the final goal being the improvement of the buttery and creamy aroma in dairy products. As we have tried to show in this review, the role of the citrate metabolism largely exceeds these considerations. Citrate positive bacteria seem to be favored, in particular when the environment becomes harsh. This is the case in fermented food products. The acidification decreases the $\mathrm{pH}$ at sub-lethal levels. The energetic benefit of this metabolism allows bacteria to better withstand and, even, to dominate. Moreover, the citrate metabolism contributes to the production of toxic compounds, organic acids and diacetyl, active against many undesired (and unfortunately desired) bacteria. This could explain the capacity of LD and $\mathrm{cpLN}$ to colonize natural starters and, in the case of cpLN, to be systematically present in vegetable food products. As such, it would seem interesting to select these microorganisms as starters, and not only for aroma production. Inevitably, some questions arise from this review. In particular, if we consider the advantages of the citrate metabolism, we can wonder why citrate positive bacteria are not the sole populations enumerated in complex natural starters. This question can be enlarged to all the citrate positive bacteria-including a lot of pathogenic Gram negative bacteria. We tried to focus on the different factors that influence the citrate metabolism. Is it then possible to use this knowledge to pilot the food making of traditional foods, to prevent/to control growth of undesirable (food spoiling and/or foodborne pathogenic) microorganisms or to improve their "typicality"? On the fringe of these questions, many technical problems have to be solved. Among them, the instrumental means to detect diacetyl have to be improved. Within the perspective of protecting people against infections, the ecological implications of citrate metabolism might be crucial in the future, and not only in Western countries. In many regions worldwide, the consumption of contaminated food products is a major sanitary concern. The addition of citrate positive bacteria in fermented food products could be then a means, among others, to better control the occurrence of infections or intoxications due to foodborne pathogenic microorganisms.

\section{Acknowledgements}

The authors would like to thank Carl Holland for English corrections.

\section{References}

[1] García-Quintáns, N.G., Repizo, G., Magni, C., López, P., Mayo, B. and Pérez-Martínez, G. (2008) Citrate Metabolism 
and Aroma Compound Production in Lactic acid Bacteria. In: Mayo B., López P., Pérez-Martínez G., Eds., Molecular Aspects of Lactic acid Bacteria for Traditional and New Applications, Research Signpost, Kerala, 65-88.

[2] Bott, M. (1997) Anaerobic Citrate Metabolism and Its Regulation in Enterobacteria. Archives of Microbiology, 167, 78-88. http://dx.doi.org/10.1007/s002030050419

[3] Hugenholtz, J. (1993) Citrate Metabolism in Lactic Acid Bacteria. FEMS Microbiology Reviews, 12, 165-178. http://dx.doi.org/10.1016/0168-6445(93)90062-E

[4] Beuvier, E. and Buchin, S. (2004) Raw Milk Cheeses. In: Fox, P. McSweeney, P. Cogan, T. and Guinee T., Eds., Cheese: Chemistry, Physics and Microbiology, Academic Press, London, 319-345. http://dx.doi.org/10.1016/S1874-558X(04)80072-1

[5] Bartowsky, E.J. and Henschke, P.A. (2004) The "Buttery" Attribute of Wine-Diacetyl—Desirability, Spoilage and Beyond. International Journal of Food Microbiology, 96, 235-252. http://dx.doi.org/10.1016/j.ijfoodmicro.2004.05.013

[6] Cabral, M.E., Mukdsi, M.C.A., Medina De Figueroa, R.B. and González, S.N. (2007) Citrate Metabolism by Enterococcus faecium and Enterococcus durans Isolated from Goat's and Ewe's Milk: Influence of Glucose and Lactose. Canadian Journal of Microbiology, 53, 607-615. http://dx.doi.org/10.1139/w07-011

[7] De Vos, W.M. and Hugenholtz, J. (2004) Engineering Metabolic Highways in Lactococci and Other Lactic Acid Bacteria. Trends in Biotechnology, 22, 72-79. http://dx.doi.org/10.1016/j.tibtech.2003.11.011

[8] Hemme, D. and Foucaud-Scheunemann, C. (2004) Leuconostoc, Characteristics, Use in Dairy Technology and Prospects in Functional Foods. International Dairy Journal, 14, 467-494. http://dx.doi.org/10.1016/j.idairyj.2003.10.005

[9] Minervini, F., et al. (2010) Robustness of Lactobacillus plantarum Starters during Daily Propagation of Wheat Flour Sourdough Type I. Food Microbiology, 27, 897-908. http://dx.doi.org/10.1016/j.fm.2010.05.021

[10] Hugenholtz, J. and Kleerebezem, M. (1999) Metabolic Engineering of Lactic Acid Bacteria: Overview of the Approaches and Results of Pathway Rerouting Involved in Food Fermentations. Current Opinion in Biotechnology, 10, 492-497. http://dx.doi.org/10.1016/s0958-1669(99)00016-6

[11] Kleerebezem, M., Hols, P. and Hugenholtz, J. (2000) Lactic Acid Bacteria as a Cell Factory: Rerouting of Carbon Metabolism in Lactococcus lactis by Metabolic Engineering. Enzyme and Microbial Technology, 26, 840-848. http://dx.doi.org/10.1016/S0141-0229(00)00180-0

[12] Bourel, G., Henini, S., Krantar, K., Oraby, M., Diviès, C. and Garmyn, D (2001) Sugar Citrate Cometabolism in Leuconostoc mesenteroides. Le Lait, 81, 75-82. http://dx.doi.org/10.1051/lait:2001113

[13] Hoefnagel, M.H.N., et al. (2002) Metabolic Engineering of Lactic Acid Bacteria, the Combined Approach: Kinetic Modelling, Metabolic Control and Experimental Analysis. Microbiology, 148, 1003-1013.

[14] Hugenholtz, J., et al. (2000) Lactococcus lactis as a Cell Factory for High-Level Diacetyl Production. Applied and Environmental Microbiology, 66, 4112-4114. http://aem.asm.org/content/66/9/4112

[15] Lopez de Felipe, F., Kleerebezem, M., de Vos, W.M. and Hugenholtz, J. (1998) Cofactor Engineering: A Novel Approach to Metabolic Engineering in Lactococcus lactis by Controlled Expression of NADH Oxidase. Journal of Bacteriology, 180, 3804-3808. http://jb.asm.org/content/180/15/3804

[16] Magni, C., De Mendoza, D., Konings, W.N. and Lolkema, J.S. (1999) Mechanism of Citrate Metabolism in Lactococcus lactis: Resistance against Lactate Toxicity at Low pH. Journal of Bacteriology, 181, 1451-1457. http://jb.asm.org/content/181/5/1451

[17] Hache, C., Cachon, R., Waché, Y., Belguendouz, T., Riondet, C., Deraedt, A. and Diviès, C. (1999) Influence of LactoseCitrate Co-Metabolism on the Differences of Growth and Energetics in Leuconostoc lactis, Leuconostoc mesenteroides ssp. mesenteroides and Leuconostoc mesenteroides ssp. cremoris. Systematic and Applied Microbiology, 22, 507-513. http://dx.doi.org/10.1016/S0723-2020(99)80002-2

[18] Sánchez, C., Neves, A.R., Cavalheiro, J., Dos Santos, M.M., García-Quintáns, N., López, P. and Santos, H. (2008) Contribution of Citrate Metabolism to the Growth of Lactococcus lactis CRL264 at Low pH. Applied and Environmental Microbiology, 74, 1136-1144. http://dx.doi.org/10.1128/aem.01061-07

[19] Konings, W.N. (2002) The Cell Membrane and the Struggle for Life of Lactic Acid Bacteria. Antonie van Leeuwenhoek, 82, 3-27. http://dx.doi.org/10.1023/a:1020604203977

[20] Marty-Teysset, C., Lolkema, J.S., Schmitt, P., Diviès, C. and Konings, W.N. (1996) The Citrate Metabolic Pathway in Leuconostoc mesenteroides: Expression, Amino Acid Synthesis, and $\alpha$-Ketocarboxylate Transport. Journal of Bacteriology, 178, 6209-6215. http://jb.asm.org/content/178/21/6209

[21] Martín, M., Magni, C., López, P. and de Mendoza, D. (2000) Transcriptional Control of the Citrate-Inducible citMCDEFGRP Operon, Encoding Genes Involved in Citrate Fermentation in Leuconostoc paramesenteroides. Journal of Bacteriology, 182, 3904-3912. http://dx.doi.org/10.1128/JB.182.14.3904-3912.2000 
[22] García-Quintáns, N.G., Magni, C., De Mendoza, D. and López, P. (1998) The Citrate Transport System of Lactococcus lactis subsp. lactis biovar. diacetylactis Is Induced by Acid Stress. Applied and Environmental Microbiology, 64, 850857. http://aem.asm.org/content/64/3/850

[23] Martín, M.G., Sender, P.D., Peiru, S., De Mendoza, D. and Magni, C. (2004) Acid-Inducible Transcription of the Operon Encoding the Citrate Lyase Complex of Lactococcus lactis Biovar. diacetylactis CRL264. Journal of Bacteriology, 186, 5649-5660. http://jb.asm.org/content/186/17/5649 http://dx.doi.org/10.1128/JB.186.17.5649-5660.2004

[24] Cogan, T.M. (1981) Constitutive Nature of the Enzymes of Citrate Metabolism in Streptococcus lactis subsp. diacetylactis. Journal of Dairy Research, 48, 489-495. http://dx.doi.org/10.1017/S002202990002197X

[25] García-Quintáns, N.G., Repizo, G., Martin, M., Magni, C. and Lopez, P. (2008) Activation of the Diacetyl/Acetoin Pathway in Lactococcus lactis subsp. lactis biovar. diacetylactis CRL264 by Acidic Growth. Applied and Environmental Microbiology, 74, 1988-1996. http://aem.asm.org/content/74/7/1988 http://dx.doi.org/10.1128/AEM.01851-07

[26] Drici, H., Gilbert, C., Kihal, M. and Atlan, D. (2010) Atypical Citrate-Fermenting Lactococcus lactis Strains Isolated from Dromedary's Milk. Journal of Applied Microbiology, 108, 647-657. http://dx.doi.org/10.1111/j.1365-2672.2009.04459.x

[27] Kaneko, T., Suzuki, H. and Takahashi, T. (1987) The Effects of Metal Ions on Diacetyl Production by Streptococcus lactis subsp. diacetylactis 3022. Agricultural and Biological Chemistry, 51, 2315-2320. http://dx.doi.org/10.1271/bbb1961.51.2315

[28] Mellerick, D. and Cogan, T.M. (1981) Induction of Some Enzymes of Citrate Metabolism in Leuconostoc lactis and Other Heterofermentative Lactic Acid Bacteria. Journal of Dairy Research, 48, 497-502. http://dx.doi.org/10.1017/S0022029900021981

[29] Ramos, A., Jordan, K.N., Cogan, T.M. and Santos, H. (1994) ${ }^{13}$ C Nuclear Magnetic Resonance Studies of Citrate and Glucose Cometabolism by Lactococcus lactis. Applied and Environmental Microbiology, 60, 1739-1748. http://aem.asm.org/content/60/6/1739

[30] Bolotin, A., Wincker, P., Mauger, S., Jaillon, O., Malarme, K., Weissenbach, J., Ehrlich, S.D. and Sorokin, A. (2001) The Complete Genome Sequence of the Lactic Acid Bacterium Lactococcus lactis ssp. lactis IL1403. Genome Research, 11, 731-753.

[31] Dartois, V., Phalip, V., Schmitt, P. and Diviès, C. (1995) Purification, Properties and DNA Sequence of the D-Lactate Dehydrogenase from Leuconostoc mesenteroides subsp. cremoris. Research in Microbiology, 146, 291-302. http://dx.doi.org/10.1016/0923-2508(96)81052-7

[32] Cocaign-Bousquet, M., Garrigues, C., Loubiere, P. and Lindley, N.D. (1996) Physiology of Pyruvate Metabolism in Lactococcus lactis. Antonie van Leeuwenhoek, 70, 253-267. http://dx.doi.org/10.1007/BF00395936

[33] Fitzgerald, R.J., Doonan, S., McKay, L.L. and Cogan, T.M. (1992) Intracellular pH and the Role of D-Lactate Dehydrogenase in the Production of Metabolic End Products by Leuconostoc lactis. Journal of Dairy Research, 59, 359-367. http://dx.doi.org/10.1017/S0022029900030636

[34] Garrigues, C., Loubiere, P., Lindley, N.D. and Cocaign-Bousquet, M. (1997) Control of the Shift from Homolactic Acid to Mixed-Acid Fermentation in Lactococcus lactis: Predominant Role of the NADH/NAD ${ }^{+}$Ratio. Journal of Bacteriology, 179, 5282-5287. http://jb.asm.org/content/179/17/5282

[35] Snoep, J.L., Teixeira de Mattos, M.J., Starrenburg, M.J.C. and Hugenholtz, H. (1992) Isolation, Characterization, and Physiological Role of the Pyruvate Dehydrogenase Complex and Alpha-Acetolactate Synthase of Lactococcus lactis subsp. lactis biovar. diacetylactis. Journal of Bacteriology, 174, 4838-4841. http://jb.asm.org/content/174/14/4838

[36] Henriksen, C.M. and Nilsson, D. (2001) Redirection of Pyruvate Catabolism in Lactococcus lactis by Selection of Mutants with Additional Growth Requirements. Applied Microbiology and Biotechnology, 56, 767-775. http://dx.doi.org/10.1007/s002530100694

[37] Melchiorsen, C.R., Jokumsen, K.V., Villadsen, J., Johnsen, M.G., Israelsen, H. and Arnau, J. (2000) Synthesis and Posttranslational Regulation of Pyruvate Formate-Lyase in Lactococcus lactis. Journal of Bacteriology, 182, 47834788. http://dx.doi.org/10.1128/JB.182.17.4783-4788.2000

[38] Condon, S. (1987) Responses of Lactic Acid Bacteria to Oxygen. FEMS Microbiology Letters, 46, $269-280$. http://dx.doi.org/10.1016/0378-1097(87)90112-1

[39] Thomas, T.D., Turner, K.W. and Crow, V.L. (1980) Galactose Fermentation by Streptococcus lactis and Streptococcus cremoris: Pathways, Products, and Regulation. Journal of Bacteriology, 144, 672-682. http://jb.asm.org/content/144/2/672

[40] Hugenholtz, J. and Starrenburg, M.J.C. (1992) Diacetyl Production by Different Strains of Lactococcus lactis subsp. lactis var. diacetylactis and Leuconostoc spp. Applied Microbiology and Biotechnology, 38, 17-22. 
http://dx.doi.org/10.1007/BF00169412

[41] Pudlik, A.M. and Lolkema, J.S. (2011) Citrate Uptake in Exchange with Intermediates in the Citrate Metabolic Pathway in Lactococcus lactis IL1403. Journal of Bacteriology, 193, 706-714. http://dx.doi.org/10.1128/JB.01171-10

[42] Phalip, V., Schmitt, P. and Divies, C. (1995) Purification and Characterization of the Catabolic $\alpha$-Acetolactate Synthase from Leuconostoc mesenteroides subsp. cremoris. Current Microbiology, 31, 316-321. http://dx.doi.org/10.1007/BF00314587

[43] Boumerdassi, H., Desmazeaud, M., Monnet, C., Boquien, C.Y. and Corrieu, G. (1996) Improvement of Diacetyl Production by Lactococcus lactis ssp. lactis CNRZ 483 through Oxygen Control. Journal of Dairy Science, 79, 775-781. http://dx.doi.org/10.3168/jds.S0022-0302(96)76425-1

[44] Cogan, J.F., Walsh, D. and Condon, S. (1989) Impact of Aeration on the Metabolic End-Products Formed from Glucose and Galactose by Streptococcus lactis. Journal of Applied Microbiology, 66, 77-84. http://dx.doi.org/10.1111/j.1365-2672.1989.tb02457.x

[45] Monnet, C., Phalip, V., Schmitt, P. and Divies, C. (1994) Comparison of $\alpha$-Acetolactate Synthase and $\alpha$-Acetolactate Decarboxylase in Lactococcus spp. and Leuconostoc spp. Biotechnology Letters, 16, 257-262. http://dx.doi.org/10.1007/BF00134622

[46] Cogan, T.M., Fitzgerald, R.J. and Doonan, S. (1984) Acetolactate Synthase of Leuconostoc lactis and Its Regulation of Acetoin Production. Journal of Dairy Research, 51, 597-604. http://dx.doi.org/10.1017/S002202990003291X

[47] McCourt, J.A. and Duggleby, R.G. (2006) Acetohydroxyacid Synthase and Its Role in the Biosynthetic Pathway for Branched-Chain Amino Acids. Amino Acids, 31, 173-210. http://dx.doi.org/10.1007/s00726-005-0297-3

[48] Cocaign-Bousquet, M., Garrigues, C., Novak, L., Lindley, N.D. and Loublere, P. (1995) Rational Development of a Simple Synthetic Medium for the Sustained Growth of Lactococcus lactis. Journal of Applied Microbiology, 79, 108116. http://dx.doi.org/10.1111/j.1365-2672.1995.tb03131.x

[49] Godon, J.J., Delorme, C., Bardowski, J., Chopin, M.C., Ehrlich, S.D. and Renault, P. (1993) Gene Inactivation in Lactococcus lactis: Branched-Chain Amino Acid Biosynthesis. Journal of Bacteriology, 175, 4383-4390. http://jb.asm.org/content/175/14/4383

[50] Goupil-Feuillerat, N., Cocaign-Bousquet, M., Godon, J.J., Ehrlich, S.D. and Renault, P. (1997) Dual Role of AlphaAcetolactate Decarboxylase in Lactococcus lactis subsp. lactis. Journal of Bacteriology, 179, 6285-6293. http://jb.asm.org/content/179/20/6285

[51] Aymes, F., Monnet, C. and Corrieu, G. (1999) Effect of $\alpha$-Acetolactate Decarboxylase Inactivation on $\alpha$-Acetolactate and Diacetyl Production by Lactococcus lactis subsp. lactis biovar. diacetylactis. Journal of Bioscience and Bioengineering, 87, 87-92. http://dx.doi.org/10.1016/s1389-1723(99)80013-9

[52] Park, S.H., Xing, R. and Whitman, W.B. (1995) Nonenzymatic Acetolactate Oxidation to Diacetyl by Flavin, Nicotinamide and Quinone Coenzymes. Biochimica et Biophysica Acta, 1245, 366-370. http://dx.doi.org/10.1016/0304-4165(95)00103-4

[53] Rondags, E., Stien, G., Germain, P. and Marc, I. (1996) Kinetic Study of the Chemical Reactivity of $\alpha$-Acetolactate as a Function of $\mathrm{pH}$ in Water, and in Fresh and Fermented Culture Media Used for Lactococcus lactis spp. lactis biovar. diacetylactis Cultivation. Biotechnology Letters, 18, 747-752. http://dx.doi.org/10.1007/BF00127882

[54] Crow, V.L. (1990) Properties of 2,3-Butanediol Dehydrogenases from Lactococcus lactis subsp. lactis in Relation to Citrate Fermentation. Applied and Environmental Microbiology, 56, 1656-1665. http://aem.asm.org/content/56/6/1656

[55] Rattray, F.P., Walfridsson, M. and Nilsson, D. (2000) Purification and Characterization of a Diacetyl Reductase from Leuconostoc pseudomesenteroides. International Dairy Journal, 10, 781-789. http://dx.doi.org/10.1016/s0958-6946(00)00103-5

[56] Bassit, N., Boquien, C.Y., Picque, D. and Corrieu, G. (1993) Effect of Initial Oxygen Concentration on Diacetyl and Acetoin Production by Lactococcus lactis subsp. lactis biovar. diacetylactis. Applied and Environmental Microbiology, 59, 1893-1897. http://aem.asm.org/content/59/6/1893

[57] Gilliland, S.E., Anna, E.D. and Speck, M.L. (1970) Concentrated Cultures of Leuconostoc citrovorum. Applied Microbiology, 19, 890-893. http://aem.asm.org/content/19/6/890

[58] Pack, M.Y., Vedamuthu, E.R., Sandine, W.E., Elliker, P.R. and Leesment, H. (1968) Effect of Temperature on Growth and Diacetyl Production by Aroma Bacteria in Single- and Mixed-Strain Lactic Cultures. Journal of Dairy Science, 51, 339-344. http://dx.doi.org/10.3168/jds.S0022-0302(68)86987-5

[59] Petit, C., Vilchez, F. and Marczak, R. (1989) Influence of Citrate on the Diacetyl and Acetoin Production by Fully Grown Cells of Streptococcus lactis subsp. diacetylactis. Current Microbiology, 19, 319-323. http://dx.doi.org/10.1007/bf01570108

[60] Rattray, F.P., Myling-Petersen, D., Larsen, D. and Nilsson, D. (2003) Plasmid-Encoded Diacetyl (Acetoin) Reductase 
in Leuconostoc pseudomesenteroides. Applied and Environmental Microbiology, 69, 304-311. http://dx.doi.org/10.1128/AEM.69.1.304-311.2003

[61] Pedersen, M.B., Gaudu, P., Lechardeur, D., Petit, M.A. and Gruss, A. (2012) Aerobic Respiration Metabolism in Lactic Acid Bacteria and Uses in Biotechnology. Annual Review of Food Science and Technology, 3, 37-58. http://dx.doi.org/10.1146/annurev-food-022811-101255

[62] Marty-Teysset, C., Lolkema, J.S., Schmitt, P., Divies, C. and Konings, W.N. (1995) Membrane Potential-Generating Transport of Citrate and Malate Catalyzed by CitP of Leuconostoc mesenteroides. Journal of Biological Chemistry, 270, 25370-25376. http://dx.doi.org/10.1074/jbc.270.43.25370

[63] Poolman, B., Bosman, B., Kiers, J. and Konings, W. (1987) Control of Glycolysis by Glyceraldehydes-3-Phosphate Dehydrogenase in Streptococcus cremoris and Streptococcus lactis. Journal of Bacteriology, 169, 5887-5890. http://jb.asm.org/content/169/12/5887

[64] Konings, W.N., Lolkema, J.S. and Poolman, B. (1995) The Generation of Metabolic Energy by Solute Transport. Archives of Microbiology, 164, 235-242. http://dx.doi.org/10.1007/s002030050260

[65] Belguendouz, T., Cachon, R. and Diviès, C. (1997) pH Homeostasis and Citric Acid Utilization: Differences between Leuconostoc mesenteroides and Lactococcus lactis. Current Microbiology, 35, 233-236. http://dx.doi.org/10.1007/s002849900244

[66] Cogan, T.M. (1987) Co-Metabolism of Citrate and Glucose by Leuconostoc spp.: Effects on Growth, Substrates and Products. Journal of Applied Microbiology, 63, 551-558. http://dx.doi.org/10.1111/j.1365-2672.1987.tb02726.x

[67] Kimoto, H., Nomura, M. and Suzuki, I. (1999) Growth Energetics of Lactococcus lactis subsp. lactis biovar diacetylactis in Cometabolism of Citrate and Glucose. International Dairy Journal, 9, 857-863. http://dx.doi.org/10.1016/S0958-6946(00)00011-X

[68] Starrenburg, M. and Hugenholtz, J. (1991) Citrate Fermentation by Lactococcus and Leuconostoc spp. Applied and Environmental Microbiology, 57, 3535-3540. http://aem.asm.org/content/57/12/3535

[69] Schmitt, P. and Divies, C. (1992) Effect of Varying Citrate Levels on $\mathrm{C}_{4}$ Compound Formation and on Enzyme Levels of Leuconostoc mesenteroides subsp. cremoris Grown in Continuous Culture. Applied Microbiology and Biotechnology, 37, 426-430. http://dx.doi.org/10.1007/BF00180962

[70] Moon, N.J. (1983) Inhibition of the Growth of Acid Tolerant Yeasts by Acetate, Lactate and Propionate and Their Synergistic Mixtures. Journal of Applied Bacteriology, 55, 453-460. http://dx.doi.org/10.1111/j.1365-2672.1983.tb01685.x

[71] Shelef, L.A. (1994) Antimicrobial Effects of Lactates: A Review. Journal of Food Protection, 57, 445-450.

[72] Røssland, E., Langsrud, T., Granum, P.E. and Sørhaug, T. (2005) Production of Antimicrobial Metabolites by Strains of Lactobacillus or Lactococcus Co-Cultured with Bacillus cereus in Milk. International Journal of Food Microbiology, 98, 193-200. http://dx.doi.org/10.1016/j.ijfoodmicro.2004.06.003

[73] De Vuyst, L. and Vandamme, E.J. (1994) Antimicrobial Potential of Lactic Acid Bacteria. In: De Vuyst, L. and Vandamme, E.J., Eds, Bacteriocins of Lactic Acid Bacteria: Microbiology, Genetics and Applications, Blackie Academic and Professional, London, 91-142.

[74] Jay, J.M. (1982) Antimicrobial Properties of Diacetyl. Applied and Environmental Microbiology, 44, 525-532. http://aem.asm.org/content/44/3/525

[75] Güler, Z. and Gürsoy-Balcı, A.C. (2011) Evaluation of Volatile Compounds and Free Fatty Acids in Set Types Yogurts Made of Ewes', Goats' Milk and Their Mixture Using Two Different Commercial Starter Cultures during Refrigerated Storage. Food Chemistry, 127, 1065-1071. http://dx.doi.org/10.1016/j.foodchem.2011.01.090

[76] Dalmasso, M., Prestoz, S., Rigobello, V. and Demarigny, Y. (2008) Behavior of Lactococcus lactis subsp. lactis biovar. diacetylactis in a Four Lactococcus Strain Starter during Successive Milk Cultures. Food Science and Technology International, 14, 469-477. http://dx.doi.org/10.1177/1082013208100533

[77] Piard, J. and Desmazeaud, M. (1991) Inhibiting Factors Produced by Lactic Acid Bacteria. 1. Oxygen Metabolites and Catabolism End-Products. Lait, 71, 525-541. http://dx.doi.org/10.1051/lait:1991541

[78] Veringa, R.A., Verburg, E.H. and Stadhouders, J. (1984) Determination of Diacetyl in Dairy Products Containing AlphaAcetolactic Acid. Netherlands Milk and Dairy Journal, 38, 251-263.

[79] Xanthopoulos, V., Picque, D., Bassit, N., Boquien, C.Y. and Corrieu, G. (1994) Methods for the Determination of Aroma Compounds in Dairy Products: A Comparative Study. Journal of Dairy Research, 61, 289-297. http://dx.doi.org/10.1017/S0022029900028302

[80] Macciola, V., Candela, G. and De Leonardis, A. (2008) Rapid Gas-Chromatographic Method for the Determination of Diacetyl in Milk, Fermented Milk and Butter. Food Control, 19, 873-878. http://dx.doi.org/10.1016/j.foodcont.2007.08.014 
[81] Jimeno, J., Lazaro, M.J. and Sollberger, H. (1995) Antagonistic Interactions between Propionic Acid Bacteria and Non-Starter Lactic Acid Bacteria. Le Lait, 75, 401-413. http://dx.doi.org/10.1051/lait:19954-530

[82] Demarigny, Y. (2012) Fermented Food Products Made with Vegetable Materials from Tropical and Warm Countries: Microbial and Technological Considerations. International Journal of Food Science \& Technology, 47, 2469-2476.

http://dx.doi.org/10.1111/j.1365-2621.2012.03087.x 